\title{
オビスギ品種材のシロアリ抵抗性と抽出成分の組織内分布*1
}

\author{
雉子谷佳男 $* 2$, 豊海 彩 $* 2,3$, 北原龍士 $* 2$, 藤本英人 $* 4$
}

\section{Termite Resistance and Extractives Distribution of Sapwood and Heartwood of Obi-Sugi Cultivars (Cryptomeria japonica)*1}

\author{
Yoshio KiJidani*2, Aya Toyoumi*2,3, \\ Ryushi Kitahara*2 and Hideto FujImoto*4
}

\begin{abstract}
Termite resistance is one of the important wood properties of sugi. However, few studies have examined variations of termite resistance among sugi cultivars. In many previous studies, sugi heartwood extractives were identified and quantified, but few studies examined the distribution of extractives in xylem cells. In this study, we examined the termite resistance of sapwood and heartwood of Obi-sugi cultivars (sugi cultivars planted in southern Kyushu, Japan) and compared the termite resistance with that of the other sugi cultivars (Yabukuguri and Kumotoshi). We also tried to observe the distribution of extractives in xylem cells with a confocal laser scanning microscope (CLSM) by selecting the excitation/emission combination of wavelengths of lasers (Ar and HeNe). There was a significant difference of termite resistance of heartwood among Obi-sugi cultivars. However, the heartwood of Obi-sugi cultivars with greater termite resistance had the same termite resistance as the heartwood of the other sugi cultivars. The sapwood of Karatsuki (one of the Obi-sugi cultivars) had greater termite resistance than the sapwood of the other sugi cultivars. The extractives observed with a CLSM (excitation/emission combination : $488 \mathrm{~nm} / 520-576 \mathrm{~nm}$ ) (extractives A) were mainly distributed on the cell wall of tracheids. The extractives observed with a CLSM (excitation/emission combination : $633 \mathrm{~nm} / 638-642 \mathrm{~nm}$ ) (extractives B) were mainly distributed in the lumen of tracheids. There were larger amounts of extractives B in heartwood than in sapwood. In heartwood of the cultivars with great termite resistance, there were larger amounts of extractives B, especially in the cell wall of tracheids.
\end{abstract}

Keywords : sugi cultivars, termite resistance, wood extractives.

この研究では, 同一林分で生育したオビスギ15品種材および 2 他地域スギ品種材について, シ ロアリ抵抗性を明らかにした。さらに，共焦点レーザー顕微鏡（CLSM）による抽出成分の観察 方法を検討し，オビスギ品種材について抽出成分の組織内分布を明らかにした。品種によってシ ロアリ抵抗性に違いが認められたものの, オビスギ品種の心材でのシロアリ抵抗性は, 他地域ス ギ品種の心材と同程度であった。辺材であるにもかかわらず，シロアリ抵抗性をもつオビスギ品 種が含まれていた。CLSM を用いて励起波長と蛍光波長を選択することによって，2つの抽出 成分群の組織内分布を自家蛍光によって観察することができた。抽出成分の組織内分布には品種 によって特徴があり，シロアリ抵抗性に優れた品種では，抽出成分 B 群（励起波長 $633 \mathrm{~nm}$, 蛍 光波長638-642 nm）が仮道管内こうだけでなく，細胞壁中にも多量に存在した。

*1 Received March 5, 2010 ; accepted February 4, 2011.

*2 宮崎大学農学部森林科学講座 Division of Forest Science, Faculty of Agriculture, Miyazaki University, Miyazaki 889-2192, Japan

*3 京都大学生存圈研究所 Research Institute for Sustainable Humanosphere, Kyoto University, Uji 611-0011, Japan

*4 宮崎県木材利用技術センター Miyazaki Prefectural Wood Utilization Research Center, Miyakonojyo 885-0037, Japan 


\section{1. 緒言}

スギ材に打いて，建築材料としての利用を促進す るためには，まず，木材材質の変動㧍よびその原因 を明らかにすることが必要不可欠である。筆者らは, これまで, 南九州地域で生育するオビスギ品種を対 象に, 組織構造的な材質指標抒よび力学的性質の変 動およびその原因について，研究を抏こなってき $た^{1-3)}$ 。さらに，スギ材の用途拡大や利用促進のた めには, 力学的性質に加えて, 耐久性拉よびその変 動を明らかにする必要がある。木材の耐久性は薬剤 処理によって高めることができるものの, 近年, 耐 久性に優れた木材を環境に負荷をかけない方法で供 給することが求められている。したがって，スギな ど主要国産材の耐朽・耐蟻性が, 個体間差, 地域差, 遺伝的相違などと関連して評価されるべきである4) と指摘されており，スギ材のシロアリ抵抗性につい て, 基礎データの蓄積が望まれる。スギ材のシロア リ抵抗性については, オビスギ心材（タノアカ）の 殺蟻成分 ${ }^{5}$ やスギ黒心材の殺蟻成分 ${ }^{6}$ ， スギ心材の 抗蟻性への高温乾燥の影響7), 沖縄産スギ材の耐蟻 性8) が報告されている。しかし，スギ品種や精英樹 のシロアリ抵抗性についての研究は少なく, オビス ギ品種についても十分に明らかになっているとは言 い難い。

スギ材のシロアリ抵抗性は, おもに心材の抽出成 分に依存すると考えられている。スギ心材の抽出成 分の種類や含有量については, スギ品種による違 ( ${ }^{9-11)}$ ，精英樹家系による違いと生育地の影響 $\left.12-16\right)$ が報告されている。オビスギ品種（ヒダリマキおよ びタノアカ）は，精油成分が多いことから ${ }^{9)}$ ，その シロアリ抵抗性が期待される。また，精英樹におけ る抽出成分量の高さ方向変動に一定の傾向はないこ と ${ }^{17)}$ が明らかにされている。しかし，これらの研 究では, 抽出成分の種類や含有量についての知見は 得られるものの, 木材組織中でどのように抽出成分 が分布しているのかについての情報は得られない。 木材ブロックでのシロアリ摂食試験では, 晚材より も早材が食害され易いものの, 同じ早材でも早く食 害される部分とそうでない部分が観察される。この 原因として, 木材密度の変動に加えて, 抽出成分の 組織内分布の変動が推測される。抽出成分の組織内 分布は, 光学顕微鏡で観察可能であり, スギ白線帯 内層部の仮道管内こうに無色の油滴状物質が出現 し，心材部で黄色あるいは茶色に変化することが報 告されている ${ }^{18)}$ 。最近, ToF-SIMS によるスギ心材 切片中のフェルギノール分布が明らかにされ，フェ
ルギノールが仮道管壁，放射柔細胞壁，軸方向柔細 胞内容物などに均一に分布することが報告されてい る ${ }^{19)}$ 。木材のシロアリ抵抗性を明らかにする上で, 抽出成分の組織内分布について知見を得ることは重 要であるものの, 研究例は少なく, 基礎デー夕の蓄 積が望まれる。近年, 様々な分野で利用される共焦 点レーザー顕微鏡 (CLSM) は, 比較的厚い切片を 用いて，光学的な断層像を得ることができる。した がって，抽出成分を可視化できれば，仮道管内こう での抽出成分分布だけでなく, 細胞壁中への抽出成 分の侵入の様子などの情報を容易に得ることができ る。

この研究では, 同一林分で生育した33年生オビス ギ15品種材抢よび 2 他地域スギ品種材についてシロ アリ摂食試験を㧍こない，精油成分が多いとされる オビスギ品種材のシロアリ抵抗性を明らかにすると ともに, 他地域スギ品種材と比較する。さらに, CLSM を用いて, 抽出成分の簡便な観察方法を検 討し，オビスギ品種材について抽出成分の組織内分 布を明らかにする。

\section{2. 実験材料および方法}

\section{1 試験材}

宮崎県北郷町に設定された「オビスギ品種別展示 林」（17品種， 33年生）に生育するスギ人工造林木 を供試木とした。オビスギ15品種のほかに, 対照ス ギ品種としてこの展示林で生育したヤブクグリおよ びクモトオシの 2 品種, 計17品種の林木を用いた。 これらは同一林分内，同一樹齢で，正常な生育をし たものである。この林分で毎木調查を行い, 品種ご とに標準的な肥大成長をした林木から 1 品種につき 1 本を選び出し供試木とした。なお，供試木の胸高 直径は $18.6 \mathrm{~cm}$ 〜 $29.1 \mathrm{~cm}$ であった。供試木を伐倒 したのち, 根元から長さ $2 \mathrm{~m}$ ごとに玉切りして, 胸高部付近から円板を採取し，心材部㧍よび辺材部 から, $2.0 \mathrm{~cm}(\mathrm{~L}) \times 2.0 \mathrm{~cm}(\mathrm{R}) \times 2.0 \mathrm{~cm}(\mathrm{~T})$ のブッロ ク試験片を作成し，シロアリ摂食試験片とした。な お，ブロック試験片の心材および辺材中での位置は 考慮しなかった。

\section{2 シロアリ摂食試験}

試験片のシロアリ抵抗性は, ブロック試験法でシ ロアリ食害による試験片の重量減少量 $(\mathrm{g})$ とシロ アリ死虫率 $(\%)$ を測定することによって評価した。 辺材部はくり返し数を 4 とした。心材部のくり返し 数は $2 \sim 4$ で, 2 回の摂食試験結果の間に違いがみ られた品種につき 4 回おこなった。ブロック試験片 は, 恒温恒湿室（温度 $20^{\circ} \mathrm{C}$, 湿度 $60 \%$ ）で気乾状態 
にして試験に用いた。飼育容器はプラスチック容器 (直径 $10 \mathrm{~cm}$, 深さ $6 \mathrm{~cm})$ に海砂 $(65$ メッシュで, 60 ${ }^{\circ} \mathrm{C}$ で乾燥）を $30 \mathrm{~g}$ 入れ, $8 \mathrm{ml}$ の蒸留水を加えたも のを用いた。容器中央部にブロック試験片を置き, ヤマトシロアリ (Reticulitermes speratus (Kolbe)) 100 頭（職蟻 90 頭, 兵蟻 10 頭）を投入し, 温度 $28^{\circ} \mathrm{C}$, 湿度80〜 90\%のインキュベーター内で45日間飼育し た。飼育期間中は，砂の状態を観察しながら， 1〜2 $\mathrm{ml}$ の蒸留水を毎日与えた。この方法でアカマツ材 を用いた飼育をおこなったところ，72日間の飼育が 可能であった。飼育期間中に死虫数を測定し，実験 開始前に投入したシロアリ頭数に対する割合（死虫 率 $(\%)$ )を求めた。加えて, 飼育期間終了後に, 表面の砂を取り除き, 恒温恒湿室で恒量になるまで 乾燥し気乾重量を求めた。実験開始前後の気乾重量 から, 重量減少量 $(\mathrm{g})$ を算出した。死虫率や重量 減少量における品種間の違いは, 統計処理ソフト （SPSS ver. 16）を用いて分散分析によって調べた （有意水準 $p \leq 0.05 ） 。$

\section{3 抽出成分の組織内分布の CLSM 観察}

2.3.1 切片作製

シロアリ摂食試験後のブロック試験片から，ミク ロトームで厚さ 60 ～70 $\mu \mathrm{m}$ の放射および接線面切片 をつくり,封入剤（グリセリン：生理食塩水 $=9: 1$ ) で封入し，簡易プレパラートを作製した。

\subsubsection{CLSM による抽出成分の観察}

品種不明のスギ材とアカマツ材を使用して前節の 方法でプレパラートを作成し，アルゴンレーザーお よびへリウムネオンレーザーを装備した CLSM (Leica TCS-SP) を用いて, 対物レンズ40倍（oil） で観察し, 自家蛍光による抽出成分の観察が可能で あるかを検討した。この研究で使用したCLSM は, フィルターを使わず，プリズムと可変式スリットで 分光をおこなうため, 蛍光波長の設定が自由におこ なえる。しかし, 蛍光波長を励起波長に近づけすぎ ると, 励起波長を検出する場合がある。励起波長と 蛍光波長が分離できる範囲において，抽出成分を観 察するための最適な励起波長と蛍光波長を調べた。 この研究では，2本のレーザーによる各観察像を重 ね合わせた画像を用いて観察した。また, この研究 では光学的断層像で観察をおこない, 複数枚の断層 像を Z 軸方向へ重ね合わせた立体画像での観察はお こなっていない。

\section{3. 結果と考察}

\section{1 オビスギ品種材のシロアリ抵抗性 オビスギ15品種材と 2 他地域品種材（クモトオシ}

およびヤブクグリ）のシロアリ抵抗性を心材と辺材 にわけて述べる。

\subsection{1 心材}

17品種の心材でのシロアリ摂食試験における実験 開始からの日数と死虫率との関係を Fig. 1 に示す。

Fig. 1 からわかるようにトサグロおよびミゾロギで は, 実験開始から10日目にシロアリが全滅し, 最も 早く死虫率が $100 \%$ となった。その一方で, エダナ ガでは 15 日目においても死虫率が $55 \%$ と最も小さか つた。また, 精油成分が多いとされている夕ノアカ ${ }^{9)}$ では，12日目でエダナガに次いで死虫率が小さかっ た。加えて, 死虫率が $90 \%$ となるまでの日数を調べ たところ, Fig. 2 に示すように，エダナガで最も長 い日数が必要で，37日であった。Fig. 1 および Fig. 2 について品種間の違いを分散分析によって調べた ところ, 7 日目の死虫率では有意差が認められなか ったものの $(p=0.056)$, 死虫率が $90 \%$ となるまで の日数では有意差が認められた $(p=0.010)$ 。エダ ナガ以外のオビスギ品種では, 早い時期に死虫率が

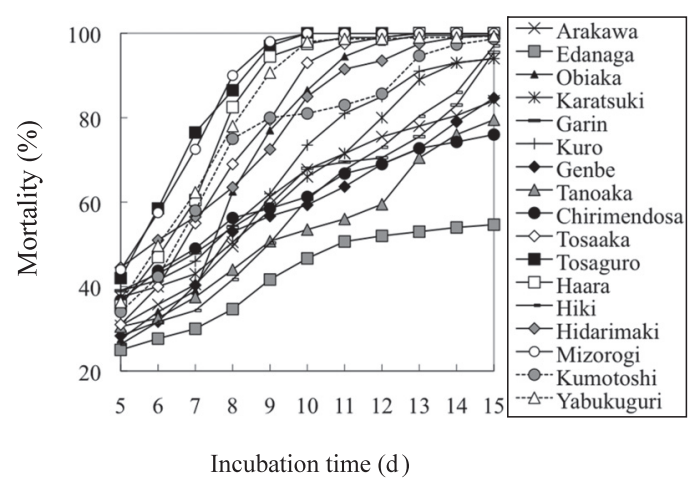

Fig. 1. Termiticidal activities of heartwood samples from sugi cultivars.

Note: Data are means of 2-4 samples of each cultivar.

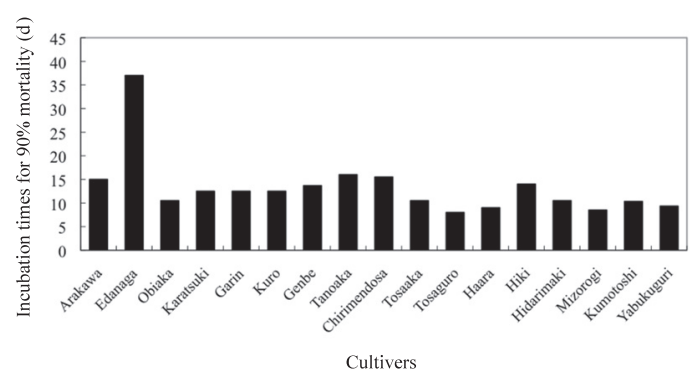

Fig. 2. Termiticidal activities of heartwood samples from sugi cultivars.

Note: Columns are means of 2-4 samples of each cultivar. 
大きくなる品種も認められたものの, 他地域品種で あるクモトオシおよびヤブクグリに比べて，死虫率 が明らかに大きな品種はなかった。

さらに, Fig. 3 に示すように，45日間の摂食試験 における重量減少量は, 死虫率とほぼ同様な結果で あり,エダナガで最も大きかった。Fig. 3 について, 品種間の違いを分散分析によって調べたところ，45 日間の摂食試験に扔ける重量減少量に有意差が認め られた（ $p=0.016 ） 。$ 精油成分が多いとされるヒダ リマキ9) 拈よびトサアカでは, 重量減少量が小さく 優れたシロアリ抵抗性を示した。このようにオビス ギ品種群には重量減少量が小さな品種も含まれてい たものの, 他地域品種であるクモトオシおよびヤブ クグリに比べて, 重量減少量が顕著に小さな品種は 認められなかった。

これらの結果から, 品種によってシロアリ抵抗性 に違いがあること, オビスギ品種の心材のシロアリ 抵抗性は他地域品種の心材と同程度であることが明 らかとなった。とくに，エダナガ心材のシロアリ抵 抗性は小さく, その用途について考慮する必要があ る。

\subsection{2 辺材}

45日間のシロアリ摂食試験において，シロアリ抵 抗性が小さい辺材であるにもかかわらず, Fig. 4 に 示すように，カラツキでは死虫率が大きくシロアリ

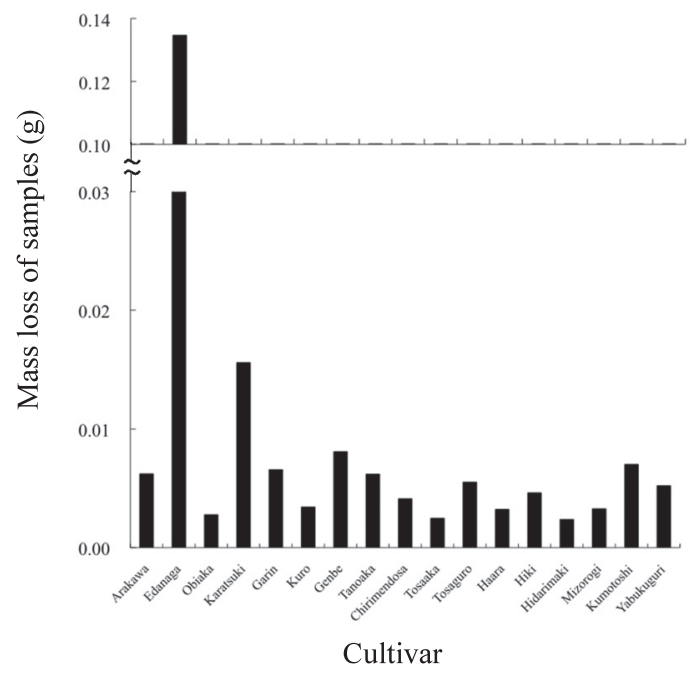

Fig. 3. Mass losses of heartwood samples from sugi cultivars.

Notes: Columns are means of 2-4 samples at each cultivar.

Mass losses of samples were measured after 45 days incubation.
が全滅した試験片が含まれていた。Fig. 4 について, 品種間の違いを分散分析によって調べたところ，45 日間の摂食試験の死虫率において有意差が認められ た $(p=0.024)$ 。

さらに, Fig. 5 に示すように, 45日間の摂食試験 における重量減少量は, 死虫率とほぼ同様な結果で あり, カラツキで最も小さかった。しかし, 重量減 少量に抢ける品種間の有意な違いは認められなかっ た $(p=0.540)$ 。これらの結果から, オビスギ品種 の辺材については, シロアリ抵抗性が他地域品種の 辺材と比べて優れている品種が含まれていることが

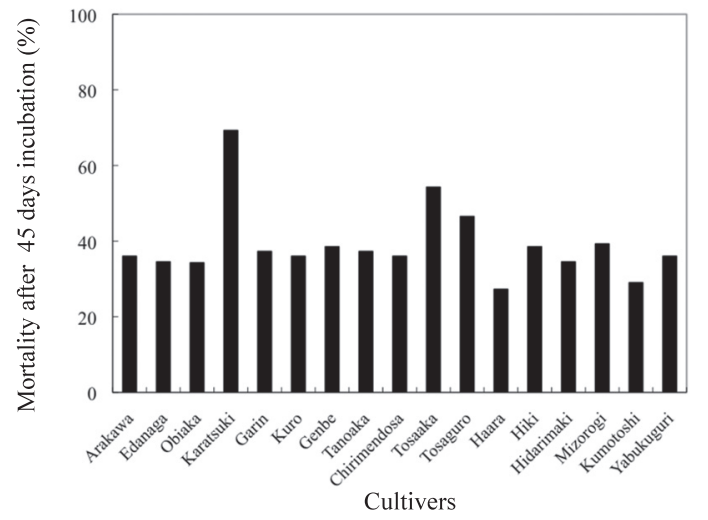

Fig. 4. Termiticidal activities of sapwood samples from sugi cultivars.

Note: Columns are means of 4 samples of each cultivar.

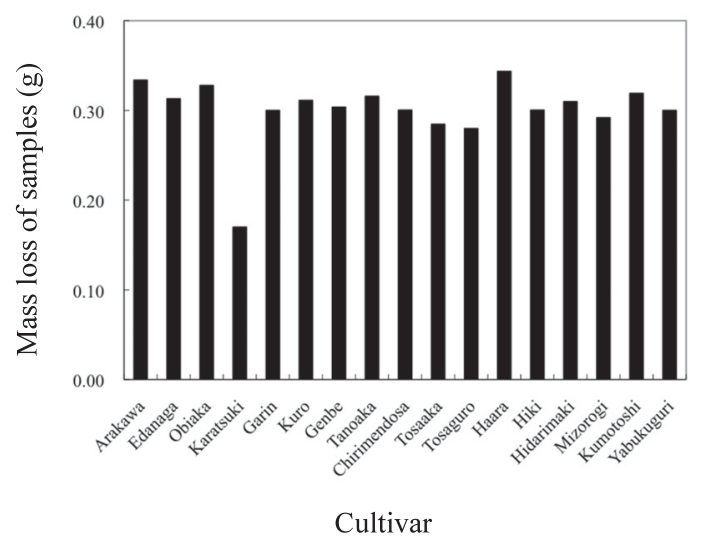

Fig. 5. Mass losses of sapwood samples from sugi cultivars.

Notes: Columns are means of 4 samples at each cultivar.

Mass losses of samples were measured after 45 days incubation. 
わかった。

かつて, 飫肥林業ではオビスギ品種を用いて, 植 栽密度 1000 本/ha 以下の疎植で木材生産をおこな い，その木材材質は曲げ易く耐久性に優れており， 弁甲材として高い評価を受けていた。この研究で用 いた試験材は, 植栽密度2000本/ha で生育した林分 から平均的な成長をした林木を試験木とした。成長 速さがシロアリ抵抗性におよぼす影響が考えられ， 今後, 品種ごとに検討する必要がある。また, 飫肥 林業の中心的な品種であったオビアカおよびトサア カは, オビスギ品種のなかでもシロアリ抵抗性が優 れていた。シロアリ抵抗性に品種間で違いが得られ たことから, 品種および植栽密度の選定などによっ て, シロアリ抵抗性により優れたスギ材生産が可能 となるかもしれない。

\section{2 抽出成分の組織内分布}

まず，品種不明のスギ材およびアカマツ材を使用 し，CLSM を用いて，自家蛍光による抽出成分の 観察方法について検討した。つぎに, この方法を用 いて，3.1節でシロアリ摂食試験に用いた試料につ いて, 品種ごとの抽出成分の組織内分布を明らかに した。

\subsubsection{CLSM による抽出成分の観察方法の検討} 品種不明のスギ心材部の放射および接線面切片を メタノールで 2 回抽出（2 時間㧍よび10時間）し,

このメタノールを濃縮したのち, プレパラート上で 乾固させた。封入剂で封入し, 抽出成分観察用プレ パラートを作成した。このプレパラートを様々な条 件で CLSM 観察したところ，2 グループの抽出成 分を自家蛍光で観察できることがわかった。これら の抽出成分のうち，1つのグループはアルゴンレー ザー488 nm で励起し, 蛍光波長520 576 nm での 検出によって, もう1つのグループはヘリウムネオ ンレーザー633 nm で励起し, 蛍光波長 $638 \sim 642 \mathrm{~nm}$ での検出で，最も良いコントラストで観察できた。 この研究では抽出成分の組織内分布の観察に重点を 置いたため, 抽出成分の同定や定量をおこなってい ない。したがって, CLSM で観察した抽出成分が 単一の化合物であるのか複数の化合物からなるのか 不明であるので，それぞれの抽出成分を抽出成分 $\mathrm{A}$ 群（励起波長 $488 \mathrm{~nm}$ ，蛍光波長 $520 ５ 76 \mathrm{~nm}$ ）およ びB 群（励起波長6 $63 \mathrm{~nm}$, 蛍光波長638 642 nm) とした。抽出成分 $\mathrm{A}$ 群の蛍光スペクトルは細胞壁と 同じであり，切片中で細胞壁と抽出成分 A 群を区別 することは困難であった。CLSM 観察像では, 細 胞壁抢よび抽出成分 $\mathrm{A}$ 群を緑色, 抽出成分 B 群を赤 色で表示した。Fig. 6 に示すように, この条件で品

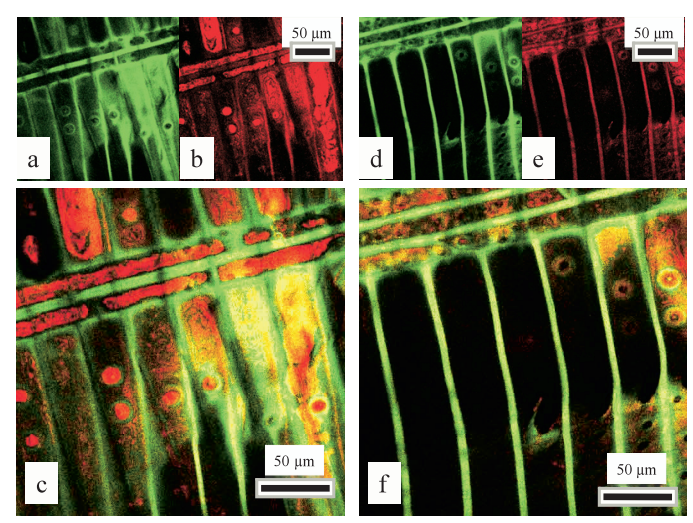

Fig. 6. Radial sections of sugi heartwood (unknown cultivar).

Notes: Sections c and $\mathrm{f}$ were examined with a CLSM (excitation/emission combination: both $488 \mathrm{~nm} / 520-576 \mathrm{~nm}$ (green color) and $633 \mathrm{~nm} /$ 638-642 nm (red color))

Sections $\mathrm{c}$ and $\mathrm{f}$ were before and after extraction by methanol, respectively.

Section c was made from sections a and b. Section $\mathrm{f}$ was made from sections $\mathrm{d}$ and $\mathrm{e}$.

種不明のスギ心材のメタノール抽出前後の切片を CLSM 観察したところ, 抽出後に細胞壁の緑色が やや少なくなっていること, 仮道管内こうの赤色が 少なくなっていることから, 抽出成分 $\mathrm{A}$ 群はおもに 細胞壁に付着して抢り, 抽出成分B群は扔もに仮道 管内こうに存在していることがわかった。Fig. 7 に 示すように, 品種不明のスギ辺材では心材に比べて, 抽出成分 B 群が細胞壁中には存在せず放射柔細胞周 辺に限られて存在しており, アカマッ辺材では極め て少なかった。Fig. 6c および Fig. 6f に示すように, スギ心材では抽出前後ともに細胞壁の一部が黄色に
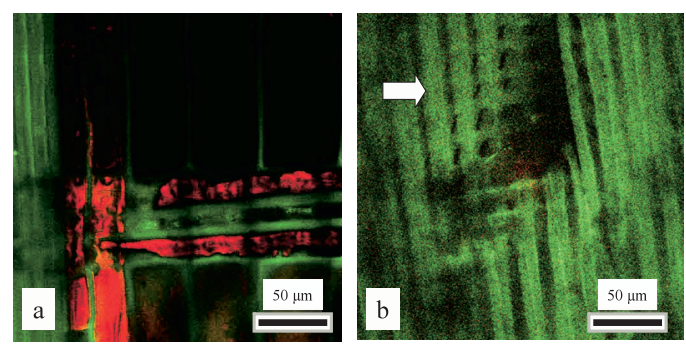

Fig. 7. Radial sections of sugi (unknown cultivar) and pine sapwood.

Legend: a : sugi sapwood, b: pine sapwood (Pinus densiflora)

Notes: Sections ( $a$ and $b$ ) were examined by the same method as that shown in Fig. 6. Arrow shows ray of pine sapwood. 
観察される。これは，Fig. 6a， Fig. 6b， Fig. 6d お よび Fig. 6e に示すように同じ場所に緑色（抽出成 分 $\mathrm{A}$ 群と細胞壁）および赤色（抽出成分 $\mathrm{B}$ 群）がと もに存在するためと考えられる。また，Fig. 6 の細 胞壁は, CLSMによる光学的断層像である。した がって，スギ心材では，Fig. 6b および Fig. 6e に示 すように抽出成分 $\mathrm{B}$ 群が細胞壁中に侵入しているこ とがわかる。抽出成分 $\mathrm{B}$ 群の蛍光スペクトルでは, 最大蛍光波長が励起波長に近いところにあり，抽出 成分 $\mathrm{A}$ 群や細胞壁で観察された明確な最大蛍光波長 が確認される蛍光スペクトルではなかった。このた め, 抽出成分 $\mathrm{B}$ 群がどのような仕組みで蛍光観察で きているのかについては疑問が残る。

3.2.2 オビスギ品種における抽出成分の組織内分 布

3.1節でのシロアリ摂食試験では，シロアリ抵抗 性に品種による違いが認められた。そこで, シロア リ抵抗性が異なるオビスギ品種材で抽出成分の組織 内分布に違いがあるのかを探るために，シロアリ摂 食試験をおこなった試験片をCLSM 観察した。Fig. 8 に示すように, オビスギ品種材抢よび他地域品種 材について, メタノール抽出前, 抽出後および乾固 させた抽出成分のプレパラートを観察した。3.2.1で 示した観察方法で, この研究で用いたスギ品種の抽 出成分の組織内分布を明らかにすることができた。

\section{(a) 心材}

心材のシロアリ抵抗性に特徴のみられた品種につ いて, 抽出成分の組織内分布を Fig. 9 に示す。死虫 率が大きく, 殺蟻性に優れた品種と考えられるトサ グロ（Fig. 9a）では，仮道管内こうが抽出成分B 群 で充填されており, 細胞壁も黄色の部分が多く, 抽 出成分 $\mathrm{B}$ 群が細胞壁まで染み込んでいることがわか

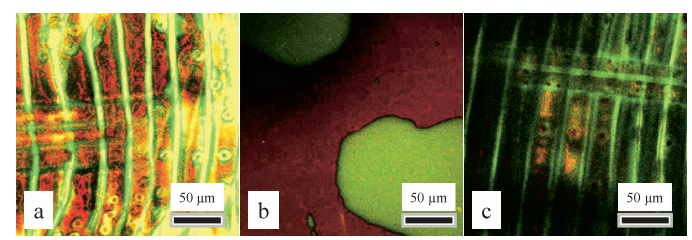

Fig. 8. Radial sections and extractives of heartwood of Obi-sugi cultivar (chirimendosa).

Legend: a: heartwood before extraction by methanol, $b$ : extractives of heartwood, $c$ : heartwood after extraction by methanol

Notes: Sections ( $a, b$ and $c$ ) were examined by the same method as that shown in Fig. 6 .

Extractives of heartwood (b) was obtained by drying the methanol used for extraction on the slide glass.

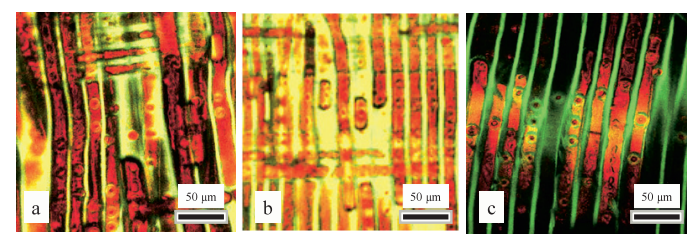

Fig. 9. Extractives distributions in heartwood of Obi-sugi cultivars.

Legend: a: Tosaguro, b: Tosaaka, c : Edanaga

Notes: Tosaguro was the cultivar with heigher termiticidal activities (Fig. 1).

Tosaaka was the cultivar with smaller mass loss of samples (Fig. 3).

Edanaga was the cultivar with lower termiticidal activities (Fig. 1), and larger mass loss of samples (Fig. 3). Sections (a, b and c) were examined by the same method as that shown in Fig. 6.

る。重量減少量が小さくシロアリ食害をほとんど受 けなかったトサアカ（Fig. 9b）では, 細胞壁が濃い 黄色になって扔り, 抽出成分 B 群はより多量に細胞 壁中に存在していると考えられた。一方, 死虫率が 小さく, 重量減少量が大きくシロアリ抵抗性に劣る と考えられるエダナガ (Fig. 9c) では, 抽出成分 B 群は仮道管内こうに少なく, 細胞壁が緑色であるこ とから, 抽出成分 $\mathrm{B}$ 群の細胞壁への染み込みも認め られなかった。シロアリ抵抗性が平均的な值を示し たチリメンドサでは, Fig. 8a のように細胞壁への 抽出成分の侵入が多い部分と, 抽出成分の侵入の少 ない部分が混在した。前述したように，ヒダリマキ および夕ノアカは精油成分が多いことが報告されて いる9)。ヒダリマキでは，仮道管内こうと細胞壁中 に抽出成分 B 群が多量に存在して扮り, Fig. 1,

Fig. 2 および Fig. 3 に示すように, オビスギ品種の なかでも優れたシロアリ抵抗性を示した。タノアカ でも, 細胞壁中に抽出成分 B 群が多量に存在したも のの, 仮道管内こうの抽出成分 $\mathrm{B}$ 群がやや少なく,

Fig. 1 でみられるように, 死虫率が小さかった。

(b) 辺材

辺材のシロアリ抵抗性に特徴のみられた品種につ いて, 抽出成分の組織内分布を Fig. 10に示す。辺 材のなかでも, 死虫率が小さく, 重量減少量が大き くシロアリ抵抗性に劣ると考えられるハアラ辺材 （Fig. 10b）では, 抽出成分 B 群は放射柔細胞周辺に 限られ, 細胞壁が緑色であることから, 抽出成分 $\mathrm{B}$ 群は細胞壁中に存在しなかった。カラツキ以外の品 種の辺材は, ハアラと同様に抽出成分 B 群が細胞壁 中に存在することはなかった。一方で, 辺材である にもかかわらずシロアリが全滅した試験片が含まれ 


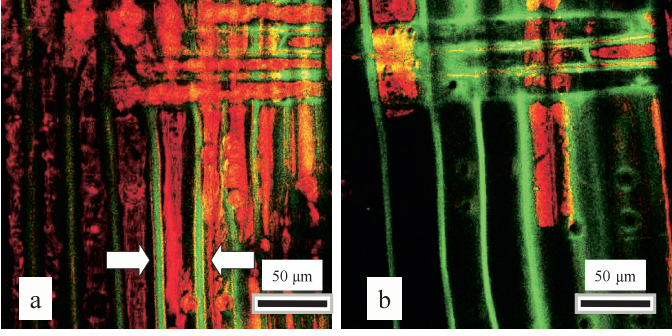

Fig. 10. Extractives distributions in sapwood of Obisugi cultivars.

Legend: a : Karatsuki, b : Haara

Notes: Karatsuki was the cultivar with heigher termiticidal activities (Fig. 4) and smaller mass loss of samples (Fig. 5). Haara was the cultivar with lower termiticidal activities (Fig. 4) and larger mass loss of samples (Fig. 5).

Arrows show penetration of extractives to the cell wall.

Sections ( $a$ and $b$ ) were examined by the same method as that shown in Fig. 6 .

て扔り，また重量減少量も最も小さく，シロアリ抵 抗性に優れていると考えられるカラッキ辺材 (Fig. 10a）では，仮道管内こうが抽出成分 B 群で充填さ れていた。心材のように, 細胞壁が黄色に観察され ることはなく, 抽出成分 B 群が細胞壁中に多量に存 在することはなかったものの, Fig. 10a の矢印で示 すように, 細胞壁への抽出成分 $\mathrm{B}$ 群の部分的な侵入 が観察された。抽出成分の組織内分布は光学顕微鏡 でも観察が可能であるものの ${ }^{18)}$ ，押もに仮道管内こ うに存在する抽出成分に有効であると考えられる。 CLSM の光学的断層像では, 細胞壁中への抽出成 分 $\mathrm{B}$ 群の侵入が観察可能であり, より多くの情報が 得られることがわかった。

3.2.3 抽出成分の組織内分布とシロアリ抵抗性に ついて

前節での観察結果から，シロアリ抵抗性に優れた 品種の心材では, 抽出成分 B 群が細胞壁中に分布し て抢り, 細胞壁中に抽出成分 $\mathrm{B}$ 群の侵入が少ない品 種ではシロアリ抵抗性が劣っていた。仮道管内こう に抽出成分が存在しても, 細胞壁中に侵入していな ければ，シロアリは仮道管内こうの抽出成分を避け て細胞壁を食害するのかもしれない。

辺材では, 細胞壁中に抽出成分 B 群がほとんど存 在しなかった。一方, ほとんどの心材では, 細胞壁 への抽出成分 B 群の侵入が観察された。シロアリ抵 抗性が認められたカラッキ辺材では, 細胞壁への部 分的な抽出成分 $\mathrm{B}$ 群の侵入が観察された。これらの
ことから，心材化にともない抽出成分 B 群は放射柔 細胞から仮道管内こうに広がり, やがて細胞壁中ま で侵入していくと考えられる。仮道管内こう間の抽 出成分 $\mathrm{B}$ 群の移動は, 有縁壁孔が赤色に観察される ことから (Fig. 6c), 有縁壁孔を通って広がると考 えられる。また, チリメンドサのように同じ試験片 でも, 試験片内の場所によって, 抽出成分 B 群の組 織内分布に変動がある品種があった。品種によって, 心材化にともなう抽出成分 B 群の広がり方に違いが あり，そのために抽出成分の組織内分布が異なり，

シロアリ抵抗性に影響をおよぼしていると推測され た。

今後, 抽出成分の組織内分布の CLSM 画像を画 像解析などによって定量化する方法を検討し, シロ アリ抵抗性との関係を明らかにする必要がある。さ らに, 品種ごとに, 心材化にともなう抽出成分の組 織内分布について, その進行過程や心材内部位によ る変動について詳細に検討する必要がある。

\section{4. 結 論}

この研究では, 同一林分で生育した33年生オビス ギ15品種材および 2 他地域スギ品種材について, シ ロアリ摂食試験によってシロアリ抵抗性を明らかに した。さらに，共焦点レーザー顕微鏡（CLSM）に よる抽出成分の簡便な観察方法を検討し, 抽出成分 の組織内分布を明らかにした。その結果, 以下の結 論を得た。

1. 品種によってシロアリ抵抗性に違いが認められ た。トサグロ心材でシロアリ抵抗性が大きく，エ ダナガ心材でシロアリ抵抗性が小さいこと, カラ ツキ辺材がシロアリ抵抗性をもつことがわかった。 2. オビスギ品種の心材のシロアリ抵抗性は, 他地 域のスギ品種の心材にくらべて同程度であり, 辺 材のシロアリ抵抗性では, 他地域のスギ品種の辺 材にくらべて優れた品種が含まれていることがわ かった。

3. CLSM を用いて励起波長と蛍光波長を選択する ことによって，2つの抽出成分群の組織内分布を 自家蛍光によって観察することができた。

4. 抽出成分の組織内分布には品種によって特徵が あり, シロアリ抵抗性に優れた品種では, 抽出成 分 B 群（励起波長633 nm, 蛍光波長638 642 nm）が仮道管内こうだけでなく，細胞壁中にも 多量に存在した。

\section{文献}

1）雉子谷佳男, 北原龍士：材料 $\mathbf{5 2}(4), 336-340$ 
(2003).

2）雉子谷佳男, 北原龍士：材料 54(4), 377-380 (2005).

3）雉子谷佳男, 北原龍士：木材学会誌 55, 198206 (2009).

4）土居修一：木材学会誌 51, 52-54（2005）.

5）曽我部昭好, 金城一彦, 阿部フミ子, 山内辰郎, 屋我嗣良：木材学会誌 46, 124-131（2000）。

6）在原重信, 梅山明美, 坂東真也, 小武家聖哉, 伊 元信治, 小野末架子, 吉川和子, 網田克明, 橋本 茂：木材学会誌 50, 413-421（2004）.

7) 狩野仁美, 澁谷 栄, 林 和男, 飯島泰男, 土居 修一：木材学会誌 50, 91-98 (2004).

8）嘉手苅幸男, 金城一彦, 屋我嗣良：木材学会誌 50, 404-412 (2004).

9）長潰静男, 田崎正人：木材学会誌 39,1077 1083 (1993).

10）長濱静男, 田崎正人, 野村浩正, 西村慶二, 田島 正啓, 岩下幸光：木材学会誌 42, 1127-1133
(1996).

11）長濱静男, 田崎正人, 寛近智明, 西村慶二, 田島 正啓：木材学会誌 44, 282-286 (1998).

12）長濱静男, 田崎正人, 西村慶二, 田島正啓: 木 材学会誌 41, 330-333 (1995).

13）長濱静男, 岩岡達矢, 芦谷竜矢 : 木材学会誌 46, 225-230 (2000).

14）長濱静男, 塚本智樹, 鳥居信弘, 園田太志, 山野 邊太郎：木材学会誌 47, 487-492 (2001).

15）長濱静男, 藤井裕士, 園田太志, 佐々木峰子 : 木 材学会誌 48, 380-386 (2002).

16) Shibutani, S., Takata, K., Doi, S. : J. Wood Sci. 53, 285-290 (2007).

17）田村 明, 藤澤義武, 飯塚和也：木材学会誌 50, 236-242 (2004).

18) Nobuchi, T., Harada, H.: Mokuzai Gakkaishi 29, 824-832 (1983).

19) Imai, T., Tanabe, K., Kato, T., Fukushima, K. : Planta 221, 549-556 (2005). 